Tropical Journal of Pharmaceutical Research September 2017; 16 (9): 2191-2196

ISSN: 1596-5996 (print); 1596-9827 (electronic)

(C) Pharmacotherapy Group, Faculty of Pharmacy, University of Benin, Benin City, 300001 Nigeria.

All rights reserved.

Available online at http://www.tjpr.org

Original Research Article

http://dx.doi.org/10.4314/tjpr.v16i9.21

\title{
Investigation of anti-inflammatory lignans from the leaves of Symplocos sumuntia Buch-Ham ex D Don (Symplocaceae)
}

\author{
Tran Thu Huong1, Le Huyen Tram', Tran Thi Minh1, Nguyen Van Thong1, Do \\ Hoang Giang ${ }^{2}$, Nguyen Hai Dang ${ }^{3}$ and Nguyen Tien Dat ${ }^{2 *}$ \\ ${ }^{1}$ School of Chemical Engineering, Hanoi University of Science and Technology, 1-Dai Co Viet Road, ${ }^{2}$ Department of Bioactive \\ Products, Institute of Marine Biochemistry (IMBC), Vietnam Academy of Science and Technology (VAST), ${ }^{3}$ Advanced Center \\ for Bio-organic Chemistry, IMBC, VAST, 18-Hoang Quoc Viet, Cau Giay, Hanoi, Vietnam
}

*For correspondence: Email: ngtiend@imbc.vast.vn; Tel: +84437917053; Fax: +84437917054

Sent for review: 15 April 2017

Revised accepted: 25 August 2017

\begin{abstract}
Purpose: To investigate the anti-inflammatory activity of Symplocos sumuntia Buch.-Ham. ex D. Don and identify the main secondary metabolites responsible for this effect.

Methods: The in vitro anti-inflammatory activity of the plant extract and isolated compounds was determined in terms of the ability to inhibit the production of nitric oxide (NO), and expressions of iNOS and COX-2 proteins in RAW264.7 cells stimulated by lipopolysaccharide (LPS). Compounds were isolated and identified by spectroscopic methods.

Results: The methanol extract of S. sumuntia leaves showed strong inhibitory effects on nitric oxide (NO) production and expression of iNOS and COX-2 in LPS-induced RAW264.7 cells. A phytochemical assay-guided fractionation of the methanol extract of $S$. sumuntia leaves led to the isolation of four lignans which are arctigenin (1), matairesinol (2), monomethylpinoresinol (3) and pinoresinol (4). These compounds were identified for the first time from $S$. sumuntia. All four compounds inhibited the production of nitric oxide (NO), with arctigenin showing the most potent activity with half-maximal inhibitory concentration $\left(I C_{50}\right)$ value of $4.08 \mu \mathrm{M}$.

Conclusion: S. sumuntia is a promising source of anti-inflammatory agents, which may clarify to the therapeutic use of this plant in Vietamese traditional medicine.
\end{abstract}

Keywords: Symplocos sumuntia, Symplocos caudata, Lignan, Arctigenin, Anti-inflammatory

Tropical Journal of Pharmaceutical Research is indexed by Science Citation Index (SciSearch), Scopus, International Pharmaceutical Abstract, Chemical Abstracts, Embase, Index Copernicus, EBSCO, African Index Medicus, JournalSeek, Journal Citation Reports/Science Edition, Directory of Open Access Journals (DOAJ), African Journal Online, Bioline International, Open-J-Gate and Pharmacy Abstracts

\section{INTRODUCTION}

Symplocos is a genus of flowering plants with about 300 species distributed in Asia, Australia and America [1]. The genus Symplocos is well known for their traditional uses in the treatment of various diseases such as leprosy, gynecological disorders, ulcers, leucorrhea, menorrhagia, malaria, and tumefaction. Previous investigations indicated that those plants contain terpenoids, flavonoids, lignans, phenols, steroids, alkaloids, and iridoids [2]. These plants exhibited antipyretic, anti-inflammatory, antibacterial, antioxidant, and anticancer activities [2,3]. Symplocos sumuntia Buch.-Ham. ex D. Don (synonym Symplocos caudata Wall. ex G. Don, Symplocos tonkinensis Brand) is a Vietnamese traditional medicinal herb that grows in the mountainous regions at $700-1500 \mathrm{~m}$ altitude [4]. Roots, leaves and flowers of this plant have been used in traditional medicine to treat cough, tonsillitis, stomachache, inflammation, 
hyperlipidemia and hypertension [5]. This plant is exploited from natural source for medicinal purpose. There are only few reports on the chemical composition of $S$. sumuntia. Nortriterpenoid saponins, neolignans, phenolic glycosides, daucosterol, glucose, sucrose and inositol wereisolated $[6,7]$. Two other studies revealed the presence of neolignan glycosides, preneolignan glycoside, phenylpropanoid glycosides and cerebroside [8,9]. However, literature searches have shown no report on biological activities of this plant.

Inflammation is a normal protective process that responds to tissue injury. In this process, cytokines, such as interleukin (IL)-1 $\beta$, IL-6, tumor necrosis factor (TNF)- $\alpha$, and inflammatory mediator, such as NO and PEG2, are increased by activated inflammation cells. It is known that inducible nitric oxide synthase (iNOS) and cyclooxygenase-2 (COX-2), two major inflammatory mediators, are expressed in a variety of cells including macrophages in response to pro-inflammatory stimuli such as lipopolysaccharide (LPS), ILs, and TNF- $\alpha$ [10]. They are responsible for the production of $\mathrm{NO}$ and prostaglandins, which have been implicated in the tissue destruction and pathogenesis of a number of immunological and inflammatory diseases [10]. Overproduction of NO causes numerous human diseases, such as arthritis, asthma, inflammation, diabetes and cancer [11]. Therefore, an assay for inhibition of $\mathrm{NO}$ production is one of the possible ways to screen anti-inflammatory agents [12,13].

In our continuing search for anti-inflammatory agents of natural origin, we found that a methanol extract of Symplocos sumuntias trongly suppressed the production of NO in LPS-induced RAW264.7 cells (with $60.1 \%$ at a concentration of $30 \mu \mathrm{g} / \mathrm{mL}$ ). The present study aims to investigate the NO inhibition of this extract and identify the main secondary metabolites responsible for the anti-inflammatory activity of this plant.

\section{EXPERIMENTAL}

\section{Plant material}

The leaves of Symplocos sumuntia were collected at VinhPhuc Province, Vietnam in March 2013, and authenticated by Prof Huy Thai Tran, Institute of Ecology and Biological Resources, VAST. A voucher specimen (no. BKB02) was deposited at the herbarium of the School of Chemical Engineering, Hanoi University of Science and Technology.

\section{Reagents and cell culture}

All culture media and reagents were supplied by Invitrogen (Grand Island, NY). Primary and secondary antibodies were bought from Santa Cruz Technology (USA). The macrophage cell line, RAW264.7, was purchased from ATCC (USA).

\section{Assay for inhibition of NO production}

The inhibitory effect of tested samples against NO production was evaluated in RAW264.7 cells stimulated by lipopolysaccharide (LPS) as previously described [14]. The Griess reagent was used for quantification of $\mathrm{NO}$ levels and cell viability was evaluated by 3-(4,5dimethylthiazole-2-yl)-2,5-diphenyl tetrazolium bromide (MTT) uptake method.

\section{Western blot analysis}

RAW264.7 cells were plated in $6 \mathrm{~cm}$ dishes at 70 $\%$ confluence and incubated at $37{ }^{\circ} \mathrm{C}$ overnight. After pre-treatment with tested samples for 30 $\mathrm{min}$, the cells were incubated with $1 \mu \mathrm{g} / \mathrm{mL}$ LPS for another $24 \mathrm{~h}$. The cells were harvested, washed twice with ice-cold phosphate-buffered saline by centrifugation, and then lysed in lysis buffer containing $50 \mathrm{mM}$ Tris- $\mathrm{HCl}, 50 \mathrm{mM} \mathrm{NaCl}$, $1 \mathrm{mM}$ EDTA, $5 \mathrm{mM}$ sodium orthovanadate, $1 \%$ NP-40 and protease inhibitor cocktail). The cell lysates were subjected to electrophoresis on 10 $\%$ sodium dodecyl sulfate-polyacrylamide gel and then the proteins were transferred to a polyvinylidenedifluoride membrane. The membrane was blocked with $5 \%$ skim milk, and incubated overnight with primary antibodies of iNOS, COX-2 and $\alpha$-tubulin at $4{ }^{\circ} \mathrm{C}$. The corresponding HRP-conjugated secondary antibody was then added for $1 \mathrm{~h}$ incubation at room temperature. The signals were detected by enhanced chemiluminescent system (Intron, Seongnam, Korea) [15].

\section{Extraction and bioassay-guided isolation}

Air-dried and powdered leaves of Symplocos sumuntia $(4 \mathrm{~kg}$ ) were extracted three times with methanol at $40{ }^{\circ} \mathrm{C}$ under ultrasonic condition. The combined extracts were concentrated to obtain $300 \mathrm{~g}$ methanol residue, which was suspended in water $(2 \mathrm{~L})$, and then successively partitioned with $n$-hexane (1.5 L $\times 3$ times) and ethyl acetate (1.5 L $\times 3$ times). The organic layers were concentrated to give 36.6 and $66.7 \mathrm{~g}$ of $n$-hexane and ethyl acetate residues, respectively. The ethyl acetate residue (71\% inhibition of $\mathrm{NO}$ production at $30 \mu \mathrm{g} / \mathrm{mL}$ ) was subjected to chromatography on a silica gel 
column eluted with a mixture of $n$-hexane and acetone (from 100:0 to $0: 100 \mathrm{v} / \mathrm{v}$ ) togive ten fractions, F1-F10. Fraction F5 (87\% inhibition of NO production at $30 \mu \mathrm{g} / \mathrm{mL}$ ) was separated on a silica gel column eluting with $n$-hexane-acetone $(4: 1, \mathrm{~V} / \mathrm{v})$ to give four fractions, F5.1-F5.4. Fraction F5.1 (98\% inhibition of NO production at $30 \mu \mathrm{g} / \mathrm{mL}$ ) was further separated by using a silica gel column with $n$-hexanedichloromethane-ethyl acetate $(2: 6: 1, \mathrm{v} / \mathrm{v} / \mathrm{v})$ as eluent, followed by a silica gel column with $n$ hexane-dichloromethane-ethyl acetate (8:32:1, $\mathrm{v} / \mathrm{v} / \mathrm{v}$ ) to obtain compound 1 (885.8 $\mathrm{mg}$ ) and compound 3 (198.3 mg). Fraction F5.3 (92\% inhibition of NO production at $30 \mu \mathrm{g} / \mathrm{mL}$ ) was isolated on a silica gel column elute with $n$ hexane-dichloromethane-ethyl acetate (5:40:4, $\mathrm{v} / \mathrm{v} / \mathrm{v})$, followed by a RP-C18 column with methanol-water $(1: 1.2, \mathrm{v} / \mathrm{v})$ as eluent to obtain compound 2 (374.3 $\mathrm{mg}$ ) and compound 4 (7.6 $\mathrm{mg}$ ).

\section{Statistical analysis}

Each assay was repeated at least three times. Means were checked for statistical differences by Student's $t$-test with error probability set at $p<$ 0.05

\section{RESULTS}

In a screening test for the inhibition of NO production in LPS-stimulated RAW 264.7 cells, the methanol extract of $S$. sumuntia leaves (SS) showed remarkable inhibitory effect in a dosedependent manner. SS did not inhibited NO production at low concentration $(3 \mu \mathrm{g} / \mathrm{mL})$. When cells were treated with higher concentrations of SS $(10,30$ and $100 \mu \mathrm{g} / \mathrm{mL})$, the inhibition increased to 23,44 and $73 \%$, respectively (Figure 1). Since COX-2 and iNOS are two major inflammatory mediators, and the induced expression of iNOS is primarilyresponsible for the NO production, we examined SS for subsequent study on the expression of COX-2 and iNOS. Consistently, in Western blot analysis, SS also prevented the LPS-induced expressions of COX-2 and iNOS at 10 and $30 \mu \mathrm{g} / \mathrm{mL}$ (Figure $2)$. These results suggested that $S$. sumuntia might contain strong anti-inflammatory compounds.

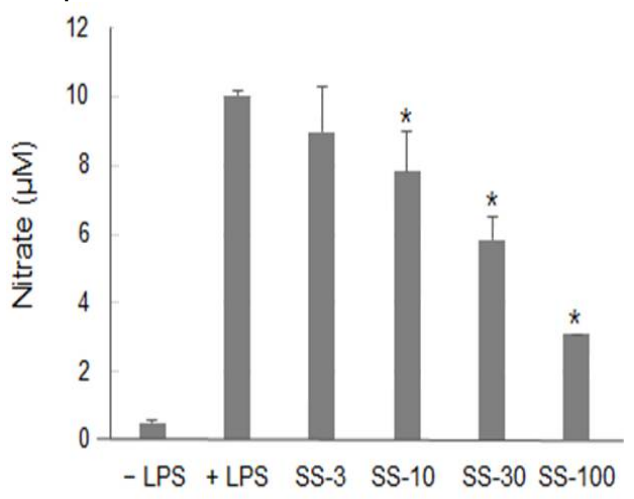

Figure 1: Effect of $S$. sumuntia extract $(\mu \mathrm{g} / \mathrm{mL})$ on the NO production in RAW264.7 cells. Cells were pretreated with tested samples for $30 \mathrm{~min}$, then incubated with $1 \mu \mathrm{g} / \mathrm{mL}$ LPS for $24 \mathrm{~h}$. NO levels were quantified by Griess assay. Bars are the standard deviations obtained from triplicated experiments; ${ }^{*} p<$ 0.05 compared to the LPS-treated control

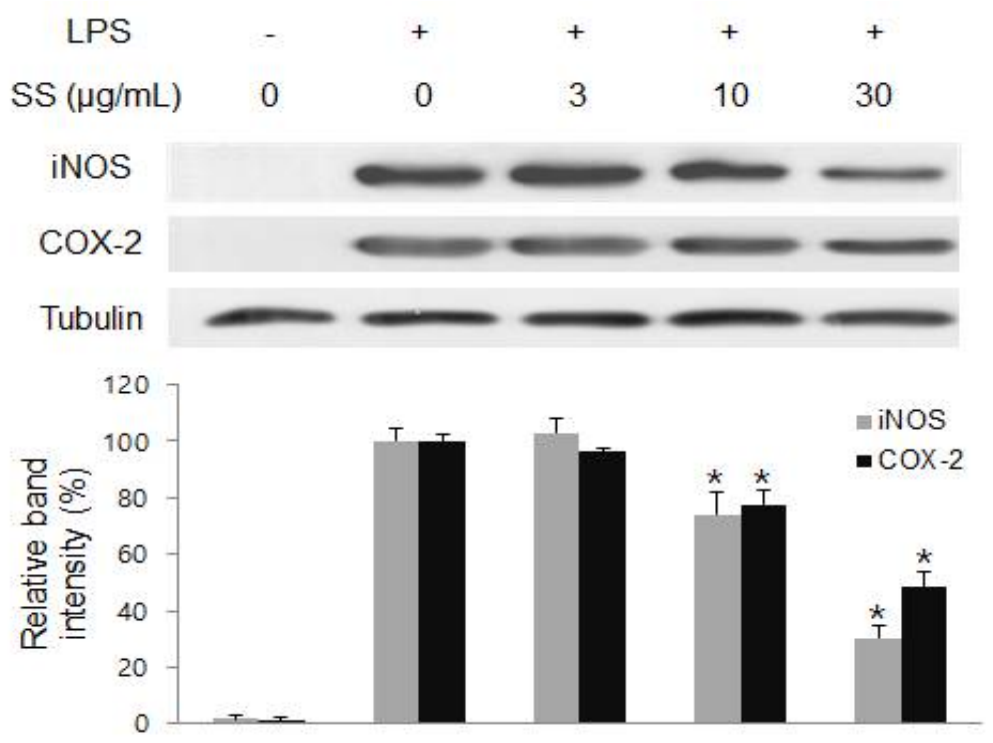

Figure 2: Effect of S. sumuntia extract $(\mu \mathrm{g} / \mathrm{mL})$ on iNOS and COX-2 expression. RAW264.7 cells were pretreated with tested samples for $30 \mathrm{~min}$, then incubated with $1 \mu \mathrm{g} / \mathrm{mL}$ LPS for indicated times. The levels of iNOS and COX-2 proteins were analyzed by Western blot. $\alpha$-Tubulin was used as protein loading control. Bars are standard deviations obtained from triplicated experiments; ${ }^{*} p<0.05$ compared to LPS-treated control 
<smiles>[R]c1ccc(C[C@@H]2COC(=O)[C@H]2Cc2ccc(O)c(OC)c2)cc1OC</smiles>

$$
\begin{aligned}
& \text { 1: } \mathrm{R}=\mathrm{OMe} \\
& \text { 2: } \mathrm{R}=\mathrm{OH}
\end{aligned}
$$<smiles>[R]c1ccc([C@@H]2OC[C@@]3(C)[C@@H](c4ccc(O)c(OC)c4)OC[C@]23C)cc1OC</smiles>

3: $\mathrm{R}=\mathrm{OMe}$

4: $\mathrm{R}=\mathrm{OH}$

Figure 3: Structures of compounds 1-4 isolated from S. sumuntia

Bioassay-guided fractionation of the methanol extract of $S$. sumuntia led to the isolation of four lignans (Figure 3). By means of spectroscopic methods including mass (MS) and nuclear magnetic resonance (NMR) spectroscopy, the isolated compounds were identifiedas arctigenin (1), matairesinol (2) [16], monomethylpinoresinol (3) and pinoresinol (4) [17]. These four compounds were isolated for the first time from Symplocos sumuntia.

The isolated compounds were tested for their inhibition of NO production in LPS-stimulated RAW264.7 cells. As shown in Table 1, arctigenin (1) was the most active compound with $I_{50}$ value of $4.08 \pm 0.26 \mu \mathrm{M}$. This effect was comparable with the reference control, cardamonin. Monomethylpinoresinol (3) exhibited moderate inhibitory effect while matairesinol (2) and pinoresinol (4) showed weaker inhibition. In the MTT assay, these compounds did not affect cell viability of RAW264.7 cells at the tested concentrations (data not shown). The inhibitory effect of compounds $\mathbf{1}$ and $\mathbf{3}$ were stronger than that of $\mathbf{2}$ and $\mathbf{4}$, respectively, suggesting that the replacement of a hydroxyl group by a methoxy group increased the inhibition of NO production.

Table 1: Inhibitory activity of NO production by compounds 1-4

\begin{tabular}{lc}
\hline Compound & $\mathbf{I C}_{50}\left(\boldsymbol{\mu} \mathbf{M}^{*}\right)$ \\
\hline Arctigenin (1) & $4.08 \pm 0.26$ \\
Matairesinol (2) & $36.9 \pm 1.85$ \\
Monomethyl pinoresinol (3) & $13.3 \pm 0.94$ \\
Pinoresinol (4) & $25.2 \pm 1.17$ \\
Cardamonin (control) & $2.80 \pm 0.18$ \\
\hline
\end{tabular}

${ }^{*}$ Values are mean $\pm S D(n=3)$

\section{DISCUSSION}

It has been reported that the plants of Symplocos genus exhibited strong anti-inflammatory activity. Jung et al. reported that several flavonoids isolated from the aerial parts of $S$. racemosa moderately inhibited $\mathrm{NO}$ production with $\mathrm{IC}_{50}$ values in the range of 42.1 - $88.2 \mu \mathrm{M}$ [18]. A triterpene and a sterol isolated from the stem bark of $S$. paniculata exhibited potent antiinflammatory activity in carrageenan induced acute paw edema in rats [19]. In a similar study, a-spinasterol isolated from $S$. spicata stem bark prevented the development of paw carrageenan edema [20]. An ethanol extract of $S$. racemosa barks exhibited anti-inflammatory activity at 100$500 \mathrm{mg} / \mathrm{kg}$ in formalin and carrageenan induced mice models [21]. Consistently, our study showed that $S$. sumuntia strongly inhibited NO production by decreasing the expression of iNOS.

Another major inflammatory mediator, COX-2, was also inhibited by $S$. sumuntia. Dibenzylbutyrolactone lignans have been known to possess a wide range of biological activitiesincluding anti-inflammation [22]. Arctigenin, one of the most common dibenzylbutyrolactone lignan, is commonly found in natural sources such as plants, animals or microorganisms. It has been shown to possess anti-inflammatory, anticancer, anti-obesity, neuroprotection, and free radical scavenging properties [23-27]. In the present study, arctigenin exhibited potent inhibitory effect against NO production. Among four compounds isolated from $S$. sumuntia leaves, this compound was found in high content, and therefore might 
be an important biomarker for quality control of this plant.

\section{CONCLUSION}

The findings of the present study show that the anti-inflammatory activity of $S$. sumuntia occurs via the inhibition of $\mathrm{NO}$ production and the expression of iNOS and COX-2 proteins. This study is the first report on the biological activity of Symplocos sumuntia. The results also explained the effective use of this plant for treatment of inflammation in traditional medicine. Thus, $S$. sumuntia is a promising source of antiinflammatory agents.

\section{DECLARATIONS}

\section{Acknowledgement}

This work was supported by a grant from National Foundation for Science and Technological Development (no. NAFOSTED 104.01-2013.29). The authors thank Professor Diep V Ca, Shenandoah University, VA, USA, for English language editing of the manuscript.

\section{Conflict of Interest}

No conflict of interest associated with this work.

\section{Contribution of Authors}

The authors declare that this work was done by the authors named in this article and all liabilities pertaining to claims relating to the content of this article will be borne by them.

\section{Open Access}

This is an Open Access article that uses a funding model which does not charge readers or their institutions for access and distributed under the terms of the Creative Commons Attribution License (http://creativecommons.org/licenses/by/ 4.0) and the Budapest Open Access Initiative (http://www.budapestopenaccessinitiative.org/rea d), which permit unrestricted use, distribution, and reproduction in any medium, provided the original work is properly credited.

\section{REFERENCES}

1. Wang $Y$, Fritsch PW, Shi S, Almeda F, Cruz BC, Kelly $L M$. Phylogeny and infrageneric classification of Symplocos (Symplocaceae) inferred from DNA sequence data. Am J Bot 2004; 91: 1901-1914.
2. Badoni R, Semwal DK, Kothiyal SK, Rawat U. Chemical constituents and biological applications of the genus Symplocos. J Asian Nat Prod Res 2010; 12: 1069-1080.

3. Acharya N, Acharya S, Shah U, Shah R, Hingorani L. A comprehensive analysis on Symplocos racemose Roxb: Traditional uses, botany, phytochemistry and pharmacological activities. J Ethnopharmacol 2016; 181: 236-251.

4. Pham HH. Flora of Vietnam. Ho Chi Minh city: Tre Publishing House; 2003.

5. Vo VC. Dictionary of Vietnamese Medicinal Plants. Hanoi: Medicine Publisher; 2004.

6. Jiang JS, Liu ZZ, Feng ZM, Yang YN, Zhang PC. A new nortriterpenoidsaponin from the roots of Symplocos caudata Wall. J Asian Nat Prod Res 2011; 13: 276-280.

7. Jiang J, Feng Z, Wang $Y$, Zhang P. New phenolics from the roots of Symplocos caudata Wall. Chem Pharm Bull 2005; 53: 110-113.

8. Huo $C$, Liang $H$, Wang $B$, Zhao $Y$. New neolignan glycosides and a new cerebroside from Symplocos caudata. Chem Nat Comp 2010; 46: 343-347.

9. Huo $C$, Liang $H$, Zhao $Y$, Wang $B$, Zhang Q. Neolignan glycosides from Symplocos caudate. Phytochem 2008; 69: 788-795.

10. Fan W, Liu $Q$, Zhu X, Wu Z, Li D, Huang F, He $H$. Regulatory effects of anesthetics on nitric oxide. Life Sci 2016; 151: 76-85.

11. Kudlow $P$, Cha DS, Carvalho AF, McIntyre RS. Nitric oxide and major depressive disorder: pathophysiology and treatment implications. CurrMol Med 2016; 16: 206-215.

12. Ilyas $U$, Katare DP, Aeri V, Naseef PP. A review on hepatoprotective and immunomodulatory herbal plants. Pharmacogn Rev 2016; 10: 66-70.

13. Luiking YC, Engelen MP, Deutz NE. Regulation of nitric oxide production in health and disease. Curr Opin Clin Nutr Metab Care 2010; 13: 97-104.

14. Dat NT, Binh PT, Quynh LTP, Huong HT, Minh CV. Sanggenon $C$ and $O$ inhibit NO production, iNOS expression and NF-KB activation in LPS-induced RAW264.7 cells. Immunopharmacol Immunotoxicol 2012; 34: 84-88.

15. Nguyen HD, Choo YY, Nguyen TD, Nguyen HN, Chau VM, Lee JH. 7-Methoxy-(9H- $\beta$-carbolin-1-il)-(E)-1propenoic acid, a $\beta$-carboline alkaloid from Eurycoma longifolia, exhibits anti-inflammatory effects by activating the Nrf2/Heme Oxygenase-1 pathway. J Cell Biochem 2016; 117: 659-670.

16. Rahman MMA, Dewick PM, Jackson DE, Lucas JA. Lignans of Forsythia intermedia. Phytochem 1990; 29: 1971-1980.

17. Miyauchi T, Ozawa S. Formation of (+)-eudesmin in Magnolia kobus DC. var. borealis Sarg. Phytochem 1998; 47: 665-670.

18. Jung M, Choi J, Chae HS, Cho JY, Kim YD, Htwe KM, Lee WS, Chin YW, Kim J, Yoon KD. Flavonoids from Symplocos racemosa. Molecules 2014; 20: 358-365. 
19. Semwal RB, Semwal DK, Semwal R, Singh R, Rawat MS. Chemical constituents from the stem bark of Symplocos paniculata Thunb. with antimicrobial, analgesic and anti-inflammatory activities. $J$ Ethnopharmacol 2011; 135: 78-87.

20. Frotan MH, Acharya SB, Frotan R, Pathak NKR, Biswas M. Pharmacological investigations on a-spinasterol isolated from Simplocos spicata. Indian J Pharmacol 1983; 15: 197-201.

21. Mehjabeen -, Ahmad M, Jahan N, Mahayrookh -, Rehman AB, Muhammad S, Obaidullah .Antidiarrhoeal, anti-inflammatory and analgesic activities of Symplocos racemesa Roxb. Bark. Pak J Pharm Sci 2014; 27: 2221-2226.

22. Solyomvary A, Beni S, Boldizsar $\quad l$. Dibenzylbutyrolactonelignans - A review of their structural diversity, biosynthesis, occurrence, identification and importance. Mini Rev Med Chem 2016; in press at http://www.eurekaselect.com/143260/article

23. Song J, Li N, Xia Y, Gao Z, Zou SF, Kong L, Yao YJ, Jiao $\mathrm{YN}, \mathrm{Yan} \mathrm{YH}$, Li SH, et al. Arctigenin treatment protects against brain damage through an anti-inflammatory and anti-apoptotic mechanism after needle insertion. Front Pharmacol 2016; 7: 182.

24. Han YH, Kee JY, Park J, Kim HL, Jeong MY, Kim DS, Jeon $Y D$, Jung $Y$, Youn $D H$, Kang J, et al. Arctigenin inhibits adipogenesis by inducing AMPK activation and reduces weight gain in high-fat diet-induced obese mice. J Cell Biochem 2016; 117: 2067-2077.

25. Zhang WZ, Jiang ZK, He BX, Liu XB. Arctigenin protects against lipopolysaccharide-induced pulmonary oxidative stress and inflammation in a mouse model via suppression of MAPK, HO-1, and iNOS signalling. Inflammation 2015; 38: 1406-1414.

26. Li D, Liu Q, Jia D, Dou D, Wang X, Kang T. Protective effect of arctigenin against MPP+ and MPTP-induced neurotoxicity. Planta Med 2014; 80: 48-55.

27. Hyam SR, Lee IA, Gu W, Kim KA, Jeong JJ, Jang SE, Han MJ, Kim DH. Arctigenin ameliorates inflammation in vitro and in vivo by inhibiting the PIJK/AKT pathway and polarizing M1 macrophages to M2-like macrophages. Eur J Pharmacol 2013; 708: 21-29. 